\title{
KERAGAMAN DAN SUMBER GEN KETAHANAN VARIETAS PADI LOKAL TERHADAP PATOGEN Pyricularia grisea PENYEBAB PENYAKIT BLAS
}

\author{
Santoso $^{1 *}$, Anggiani Nasution ${ }^{1}$, Nani Yunani ${ }^{1}$ \\ ${ }^{1}$ Balai Besar Penelitian Tanaman Padi, Jl Raya 9 Sukamandi, Subang \\ * Corresponding Author: santoso.kadrawi@gmail.com
}

\begin{abstract}
[DIVERSITY AND THE SOURCE OF RESISTANCE GENE OF LOCAL RICE VARIETIES ON THE PATHOGENIC OF Pyricularia grisea CAUSE OF BLAST DISEASE]. Local rice varieties are known to have resistance or source of genes to pests even though their productivity yield is low. The pathogen of Pyricularia grisea is a cause of blast disease, which is one of the obstacles in rice production. The research aims to characterize the resistance of local rice varieties to the pathogen of $P$. grisea and to evaluate the virulence level of $P$. grisea pathogens against local rice varieties. A total of 100 local rice varieties and check varieties are susceptible and resistant namely Kencana Bali and Situ Patenggang tested their resistance to 4 dominant pathogenic of P. grisea i.e. races $033,073,133$ and 173 . Inoculation was carried out on stages 4-5 leaves or 18-21 days after seedling in a green house. The results showed a high genetic diversity of local rice varieties against pathogenic races 033, 073, 133 and 173. Based on the response of local rice varieties resistance i.e. moderately resistant (MR), resistant (R) and susceptible (S) to pathogenic races 033,073, 133 and 173 obtained 45 resistance response patterns. Cere Bereum varieties which are local rice varieties from West Java and Situ Patenggang resistant check varieties have a resistant response to $4 P$. grisea pathogenic races used. A number of local rice varieties also show a resistant and moderately resistant response to the four pathogenic races used include Siam 11, Pare Siriendah, Menyan, Cere Manggu and Enud-Rawa Bogo. Local rice varieties Djedah and Padi Hitam (2) are local rice varieties that have a specific response of resistant or moderately resistant to race 173 . Race 133 and 173 have higher virulence rates than those of races 033 and 073 on local rice varieties. The results of this study indicate that there is a great potential for the utilization of local rice varieties, as a source of resistance genes for blast disease for the assembly of rice varieties that are resistant to blast disease.
\end{abstract}

Keyword: genetic diversity, local rice variety, blast disease, pathogen race, Pyricularia grisea

\begin{abstract}
ABSTRAK
Varietas padi lokal diketahui mempunyai ketahanan atau sumber gen terhadap hama penyakit meskipun hasil produksinya rendah. Patogen Pyricularia grisea adalah penyebab penyakit blas, merupakan salah satu kendala dalam produksi tanaman padi. Penelitian bertujuan untuk 1. mengkarakterisasi ketahanan varietas-varietas padi lokal terhadap patogen $P$. grisea dan 2. mengevaluasi tingkat virulensi patogen $P$. grisea terhadap varietas padi lokal. Sebanyak 100 varietas padi lokal dan varietas pembanding rentan dan tahan yaitu Kencana Bali dan Situ Patenggang diuji ketahanannya terhadap 4 ras patogen $P$. grisea dominan yaitu ras $033,073,133$ dan 173 . Inokulasi dilakukan pada stadia 4-5 daun atau 18-21 hari setelah semai di rumah kaca. Hasil penelitian menunjukkan adanya keragaman genetik varietas padi lokal yang tinggi terhadap ras patogen 033, 073, 133 dan 173. Berdasarkan respon ketahanan varietas padi lokal yaitu agak tahan (AT), tahan (T) dan rentan (R) terhadap ras patogen 033, 073, 133 dan 173 diperoleh 45 pola respon ketahanan. Varietas Cere Bereum yang merupakan varietas padi lokal dari Jawa Barat dan varietas pembanding tahan Situ Patenggang mempunyai respon tahan terhadap terhadap 4 ras patogen $P$. grisea yang digunakan. Sejumlah varietas padi lokal juga menunjukkan respon tahan dan agak tahan terhadap keempat ras patogen yang digunakan antara lain Siam 11, Pare Siriendah,, Menyan, Cere Manggu dan Enud-Rawa Bogo. Varietas padi lokal Djedah dan Beras Hitam (2) merupakan varietas padi lokal yang mempunyai respon spesifik tahan atau agak tahan terhadap ras 173 . Ras 133 dan 173 mempunyai tingkat virulensi yang lebih tinggi dibandingkan ras 033 dan 073 terhadap varietas padi lokal. Hasil penelitian ini menunjukkan adanya potensi yang besar pemanfaatan varietas padi lokal sebagai sumber gen ketahanan terhadap penyakit blas untuk perakitan varietas padi yang tahan penyakit blas.
\end{abstract}

Kata kunci: keragaman genetik, varietas padi lokal, penyakit blas, Pyricularia grisea 


\section{PENDAHULUAN}

Penyakit blas merupakan salah satu penyakit penting pada tanaman padi di seluruh dunia. Penyakit blas disebabkan oleh cendawan Pyricularia oryzae Cav. atau Pyricularia grisea [sinonim Magnaporthe oryzae (Hebert) Barr] (Rossman et al., 1990). Patogen $P$. grisea dapat menginfeksi tanaman padi pada fase vegetatif dan generatif. Bagian utama yang dinfeksi pada fase vegetatif adalah daun atau disebut dengan blas daun. Gejala penyakit blas daun diawali dengan bercak-bercak seperti ujung jarum yang berwarna coklat. Bercak berkembang menjadi lonjong dan membentuk seperti belah ketupat. Pada bagian tengah bercak berwarna putih abu-abu dengan tepi berwarna coklat. Pada stadia generatif, terutama pada saat pengisian biji, ditemukan gejala penyakit blas pada leher malai. Malai padi yang terinfeksi parah oleh patogen blas menimbulkan gejala busuk kering pada leher malai (Ou, 1985).

Cendawan $P$. grisea merupakan patogen yang dinamis dan mampu beradaptasi cepat dengan kondisi tanaman inang. Patogen juga mempunyai tingkat keragaman genetik yang tinggi dan kemampuan untuk menghasilkan ras baru. Santoso et al. (2019) mengidentifikasi ras P. grisea dari Papua Barat terdiri atas sembilan kelompok yaitu ras 211, 213, 241, 251, 253, 313, 333,353 dan 373. Ras yang dominan adalah ras 333 dan 373 dengan komposisi $41,18 \%$ dan $33.35 \%$. Ras yang didapatkan mempunyai tingkat virulensi yang tinggi. Ras Pyricularia yang berasal dari daerah pengembangan padi tersebut mempunyai kekhususan berupa tingkat virulensi yang lebih tinggi dibandingkan dengan ras yang ditemukan di daerah pengembangan padi di luar Papua Barat, seperti Jawa Barat, Jawa Tengah, Jawa Timur, dan Lampung (Nasution et al., 2013; Santoso \& Nasution, 2008; Sudir et al., 2014)

Luas serangan penyakit blas pada MH 2017/ 2018 seluas 24.226 ha. Persentase kejadian serangan penyakit blas yang melebihi angka prakiraan terjadi pada Musim Hujan MT 2017/2018 terdapat di sepuluh (10) provinsi yaitu provinsi Aceh, Sumatera Selatan, DIY, Jawa Timur, Banten, Bali, Kalimantan Barat, Kalimantan Selatan, Kalimantan Timur dan Papua (BBPOPT, 2019). Tingkat kehilangan hasil sangat dipengaruhi oleh kondisi iklim, patogen dan tingkat ketahanan atau kerentanan varietas padi yang digunakan. Sebagai contoh adalah kerugian hasil oleh penyakit blas pada varietas Ciherang sebesar 3,65 ton/ha atau setara dengan $61 \%$ kehilangan hasil jika dibandingkan terhadap rata-rata produksi varietas Ciherang (Suganda et al., 2016). Subiadi et al. (2016) melaporkan bahwa kehilangan hasil padi yang disebabkan penyakit blas dapat mencapai 42,84\% pada varietas Mekongga, 44,78\% pada varietas Ciherang, 56,91\% pada varietas Cigeulis, dan $64,05 \%$ pada varietas Inpari-19.

Salah satu pengelolaan pengendalian penyakit blas yang efektif adalah dengan penggunaan varietas tahan blas (Sharma et al., 2014). Pengunaan varietas tahan selain bersifat ramah lingkungan, juga efisien dalam biaya (Prabawa et al., 2015). Pemanfaatan varietas tahan seharusnya disesuaikan dengan sebaran ras yang ada di suatu daerah atau spesifik lokasi (Sudir et al., 2014).

Varietas padi lokal pada umumnya dianggap kurang mempunyai nilai ekonomis dibandingkan varietas padi unggul baru, hal ini disebabkan karena varietas padi lokal mempunyai potensi hasil rendah, umur yang dalam, mudah rebah dan kurang respon terhadap pemupukan. Sitaresmi et al. (2013) dan Turaidar et al. (2018) menyatakan bahwa beberapa plasma nutfah padi varietas lokal telah teridentifikasi tahan dan toleran terhadap cekaman biotik dan abiotik serta memiliki mutu beras yang baik. Perakitan varietas padi dengan menggunakan dan memanfaatkan keunggulan spesifik yang dimiliki varietas lokal diharapkan dapat meningkatkan keunggulan varietas padi yang dibudidayakan pada spesifik lokasi. Varietas padi lokal Klemas, Gampai, Cenggong, dan Grogol telah digunakan sebagai donor tetua untuk mendapatkan varietas padi tahan blas (Hairmansis et al., 2015). Hasil penelitian menunjukkan adanya keragaman ketahanan yang berbeda-beda pada varietas padi lokal terhadap penyakit blas daun (Nasution \& Usyati, 2015). Dua genotipe padi merah lokal yaitu Mandel dan Yaiti dilaporkan memiliki penampilan terbaik pada semua karakter ketahanan seperti periode laten, jumlah bercak berspora, jumlah bercak tidak berspora, skor tingkat ketahanan dan intensitas serangan penyakit blas daun (Prabawa et al., 2015).

Ketahanan varietas terhadap penyakit blas tidak stabil dan mudah patah ketahanannya pada kondisi lapang sehingga perlu dilakukan pencarian sumber gen tahan secara kontinu terhadap patogen $P$. grisea khususnya ras-ras dominan yang banyak ditemukan di beberapa daerah seperti ras 033, 073, 133 dan 173. Informasi ketahanan tersebut sangat diperlukan untuk mengetahui gen-gen ketahanan penyakit blas pada varietas padi lokal. Varietas-varietas padi lokal yang memiliki ketahanan terhadap penyakit blas dapat digunakan oleh para pemulia dalam rangka merakit varietas padi yang tahan terhadap penyakit blas.

\section{METODE PENELITIAN}

Penelitian dilaksanakan di Laboratorium dan Rumah kaca Balai Besar Penelitian Tanaman Padi (BB Padi) Kebun Percobaan Muara Bogor, 2017. Materi genetik yang diuji adalah varietas padi lokal sebanyak 100 varietas, varietas Kencana Bali dan Situ Patenggang sebagai varietas pembanding rentan dan tahan terhadap penyakit blas. Ras cendawan $P$. grisea yang digunakan yaitu ras 033, 073, 133 dan ras 173, merupakan rasras $P$. grisea yang dominan ditemukan di lapang. 
Varietas padi lokal dan varietas pembanding ditanam pada pot-pot plastik persegi panjang dengan ukuran $20 \mathrm{~cm} \times 10 \mathrm{~cm} \times 10 \mathrm{~cm}$, ditanam secara gogo dengan pemupukan $5 \mathrm{~g}$ Urea, 1,3 g TSP dan $1,2 \mathrm{~g} \mathrm{KCl}$ untuk setiap $10 \mathrm{~kg}$ tanah kering. Penanaman secara larikan dengan jumlah benih sebanyak $20-25$ benih untuk setiap varietas padi lokal yang diuji. Pemeliharaan tanaman dilakukan dengan melakukan penyiraman dan penyiangan gulma yang tumbuh.

Masing-masing ras $P$. grisea diperbanyak pada media kentang dekstrose agar pada cawan petri selama 7 hari. Biakan murni selanjutnya dipindahkan ke media tepung gandum agar selama 12 hari. Pada hari ke-10 setelah pemindahan dilakukan penggosokan koloni cendawan dengan menggunakan air steril yang ditambah $0.01 \mathrm{~g}$ Streptomycin/liter. Setelah digosok disimpan dalam inkubator bercahaya dengan lampu neon 20 watt selama 48 jam. Pada hari ke-12 dilakukan penggosokan ulang dengan menggunakan kuas gambar no.10 dan air steril yang mengandung Tween 20 sebanyak $0.02 \%$ untuk mendapatkan larutan spora. Kerapatan spora yang digunakan sebesar $2 \times 10^{5}$ spora/ $\mathrm{mL}$.

Inokulasi dilakukan dengan cara penyemprotan pada tanaman berumur 18 hari atau stadia 4-5 daun. Tanaman yang telah diinokulasi diinkubasikan selama 24 jam dalam ruang lembab, kemudian dipindahkan ke rumah kaca. Untuk memelihara kelembaban selama di rumah kaca dilakukan pengembunan. Pengamatan evaluasi ketahanan dilakukan pada hari ke-7 setelah inokulasi dengan menggunakan standar evaluasi IRRI (2014) (Tabel 1).

Tabel 1. Skala penyakit blas daun dan kriterianya (IRRI, 2014)

\begin{tabular}{|c|l|}
\hline Skala & Keterangan varietas \\
\hline 0 & Tidak ada gejala serangan \\
\hline 1 & Terdapat bercak-bercak sebesar ujung jarum \\
\hline 2 & $\begin{array}{l}\text { Bercak nekrotik keabu-abuan, berbentuk bundar } \\
\text { dan agak lonjong, panjang 1-2 mm dengan tepi } \\
\text { coklat }\end{array}$ \\
\hline 3 & Bercak khas blas, panjang 1-2 mm \\
\hline 4 & Luas daun terserang kurang dari 4\% luas daun \\
\hline 5 & Bercak khas blas luas daun terserang 4-10\% \\
\hline 6 & Bercak khas blas luas daun terserang 11-25\% \\
\hline 7 & Bercak khas blas luas daun terserang 26-50\% \\
\hline 8 & Bercak khas blas luas daun terserang 51-75\% \\
\hline 9 & Bercak khas blas luas daun terserang 76-100\% \\
\hline
\end{tabular}

Analisis ketahanan adalah sebagai berikut 0 $2=$ Tahan (T); 3 = Agak Tahan (AT); 4 = Agak Rentan dan 5-9= Rentan (R). Untuk analisis viru- len dan avirulen patogen ras $P$. grisea yang digunakan adalah virulen $=$ jika respon varietas lokal menunjukkan rentan atau agak rentan; avirulen = respon varietas lokal menunjukkan tahan atau agak tahan.

\section{HASIL DAN PEMBAHASAN}

Hasil penelitian menunjukkan bahwa varietas padi lokal yang diuji mempunyai respon yang beragam terhadap patogen $P$. grisea ras 033, 073, 133 dan 173. Jumlah varietas padi lokal yang menunjukkan respon tahan terhadap ras 033,073, 133 dan 173 adalah masing-masing $38 ; 15 ; 21 ; 14$ dan agak tahan sebanyak $40 ; 55 ; 44 ; 47$ varietas. Dengan demikian jumlah varietas padi lokal yang mempunyai respon tahan atau agak tahan terhadap ras 033, 073, 133 dan 173 masing-masing sebesar 78; 70; 65 dan 61 . Jumlah varietas padi lokal yang rentan adalah $22 ; 30 ; 35 ; 39$ masing-masing terhadap patogen $P$. grisea ras 033, 073, 133 dan 173. Hasil ini menunjukkan adanya keragaman genetik yang tinggi pada varietas padi lokal Indonesia (Tabel 2). Hasil penelitian Nasution \& Usyati (2015), juga mendapatkan adanya keragaman genetik yang tinggi pada varietas padi lokal terhadap penyakit blas. Hal ini menunjukkan ada potensi yang besar dalam pemanfaatan varietas-varietas lokal untuk dijadikan donor atau sumber gen ketahanan terhadap penyakit blas, yaitu perakitan varietas tahan blas khususnya ras 033, 073, 133 dan 173. Setiap varietas mempunyai respon yang berbeda-beda terhadap serangan patogen. Perbedaan respon tersebut dapat disebabkan oleh adanya perbedaan morfologi atau genetik tanaman. Faktor genetik memberikan pengaruh yang besar terhadap ketahanan varietas padi terhadap patogen di lingkungan yang endemik penyakit blas terutama pada penampakan fenotipnya (Kharisma et al., 2013).

Tabel 2. Jumlah varietas padi lokal yang menunjukkan respon tahan, agak tahan rentan terhadap ras $P$. grisea

\begin{tabular}{c|ccc|c}
\hline \multirow{2}{*}{ Ras } & \multicolumn{3}{|c|}{ Respon Varietas Lokal } & \multirow{2}{*}{ Total } \\
\cline { 2 - 4 } & Tahan & Agak Tahan & Rentan & \\
\hline 33 & 38 & 40 & 22 & 100 \\
\hline 73 & 15 & 55 & 30 & 100 \\
\hline 133 & 21 & 44 & 35 & 100 \\
\hline 173 & 14 & 47 & 39 & 100 \\
\hline
\end{tabular}

Keragaman genetik yang tinggi pada varietas padi lokal yang diuji terhadap patogen $P$. grisea dapat diketahui juga berdasarkan pola respon ketahanannya terhadap ras 033, 073, 133 dan 173. Berdasarkan pola respon tahan $(\mathrm{T})$, agak tahan (AT) dan rentan (R) didapatkan 45 pola respon ketahanan (Tabel 3).

Pola respon ketahanan 1 merupakan varietas padi lokal yang tahan terhadap 4 ras yang digunakan. 
Hanya ada 1 varietas padi lokal yaitu Cere Bereum yang menunjukkan pola respon ketahanan 1 atau tahan terhadap ras 033, 073, 133 dan 173 dengan skala penyakit 1 . Cere Bereum adalah varietas padi lokal yang berasal dari Jawa Barat. Pola respon ketahanan varietas Cere Bereum ini sama dengan varietas kontrol tahan Situ Patenggang, yang mempunyai respon tahan dengan skala penyakit 1 terhadap patogen ras 033,073 , 133 dan 173.

Varietas padi lokal yang menunjukkan respon tahan (T) atau agak tahan (AT) terhadap ras 033, 073, 133 dan 173 terdapat 12 pola respon ketahanan yaitu pola respon ketahanan $1 ; 2 ; 3 ; 6 ; 7 ; 9 ; 18 ; 19 ; 20$; 22; 24 dan 25, dengan jumlah 26 varietas padi lokal. Varietas-varietas padi lokal yang termasuk dalam pola respon ketahanan tersebut adalah Cere Bereum, Jember, Cere 2, Enud-Rawa Bogo, Muncul, Inul, Oseg, Jembar Batan, Siam 11, Obor Laut, Cungkring, Cere Manggu, Nengsih, Semati, Pare Siriendah, Basmati Sukamandi, Pae Ndina Ana, Gombal, Djambon, Lamdaur Ekor Hitam, Kewal Bereum, Cere 1, Menyan, Darma Ayu, Yoing dan Cekow (Tabel3). Sebagian besar varietas padi lokal yang mempunyai respon tahan atau agak tahan terhadap 4 ras $P$. grisea yang digunakan berasal dari Jawa Barat, sedangkan beberapa varietas padi lokal yang berasal dari lainya, yaitu Pare Sireindah (Pandeglang, Banten), Pae Ndina Ana (Konawe Selatan, Sulawesi Tenggara) dan Cekow (Pelelawan, Riau) (Tabel 4).

Terdapat 17 pola respon ketahanan yang menunjukkan respon tahan atau agak tahan terhadap 3 ras patogen yang digunakan yaitu pola respon ketahanan $4,5,8$, $10,11,12,14,15,21,23,29,30,31,35,36,38$,dan 39 dengan jumlah 36 varietas padi lokal (Tabel 3 ). Varietas padi lokal yang menunjukkan pola ketahanan tersebut adalah Lamdaur Ekor Putih, Wulung 1, Angkok, Kwatek Padang Luas, Saba, Tamleg, Ketan Hitam, Hawara Kapas 1, Si Denok, Morneng/Dasneng, Unus Birayang, Terong Ulang, Genjah Welut, Mekar Sari, Jembur Lokal, Unus, Hawara Kapas 2, Borang, Ketan Pecut 2, Kebo, Pantai Bujang Berinai, Rembang, Lakcan Empok, Srijaya Panjang, Siam Unus Kuning Tanbak Sariah, Monsua, Beras Hitam, Si Udang, Kantuna, Ketan Putih, Pare Salak, Cere Dota, Pae Lolo, HS3, Padi Bau, dan Padi Pulut Belanda (Tabel 3).

Tabel 3. Pola respon ketahanan varietas-varietas padi lokal terhadap ras 033, 073, 133 dan 173

\begin{tabular}{|c|c|c|c|c|c|c|c|c|c|c|c|}
\hline \multirow{3}{*}{$\frac{\text { No. }}{1}$} & \multirow{3}{*}{$\begin{array}{c}\begin{array}{c}\text { Pola } \\
\text { respon } \\
\text { ketahana }\end{array} \\
1 \\
\end{array}$} & \multirow{3}{*}{\begin{tabular}{|r|} 
No. Aksesi \\
9525 \\
\end{tabular}} & \multirow{3}{*}{ Nama Aksesi } & \multicolumn{8}{|c|}{ Reaksi Pyricularia grisea } \\
\hline & & & & \multicolumn{2}{|c|}{ Ras 033} & \multicolumn{2}{|c|}{ Ras 073} & \multicolumn{2}{|c|}{$\operatorname{Ras} 133$} & \multicolumn{2}{|c|}{ Ras 173} \\
\hline & & & & 1 & $\mathrm{~T}$ & 1 & $\mathrm{~T}$ & 1 & $\mathrm{~T}$ & 1 & $\mathrm{~T}$ \\
\hline 2 & & & Sitv Patenggang (kontrol taha: & 1 & $\mathrm{~T}$ & 1 & $\mathrm{~T}$ & 1 & $\mathrm{~T}$ & 1 & $\mathrm{~T}$ \\
\hline 3 & 2 & 9526 & Jember & 1 & $\mathrm{~T}$ & 1 & $\mathrm{~T}$ & 1 & $\mathrm{~T}$ & 3 & $\overline{\mathrm{AT}}$ \\
\hline 4 & & 9527 & Cere 2 & 1 & $\mathrm{~T}$ & 1 & $\mathrm{~T}$ & 1 & $\mathrm{~T}$ & 3 & AT \\
\hline 5 & 3 & 9519 & Envd-Rawa Bogo & 1 & $\mathrm{~T}$ & 1 & $\mathrm{~T}$ & 3 & $\mathrm{AT}$ & 1 & $\mathrm{~T}$ \\
\hline 6 & 4 & 9562 & Padi Ngaos & 1 & $\mathrm{~T}$ & 1 & $\mathrm{~T}$ & 3 & AT & 5 & $\bar{R}$ \\
\hline 7 & 5 & 9516 & Lamdaur Ekor Putih & 1 & $\mathrm{~T}$ & 1 & $\mathrm{~T}$ & 5 & $\mathrm{R}$ & 1 & $\mathrm{~T}$ \\
\hline 8 & 6 & 9547 & Muncul & 1 & $\bar{T}$ & 3 & $\overline{A T}$ & 1 & $\bar{T}$ & 1 & $T$ \\
\hline 9 & 7 & 7878 & Merdeka & 1 & $\bar{T}$ & 3 & $\overline{\mathrm{AT}}$ & 1 & $\mathrm{~T}$ & 3 & $\overline{\mathrm{AT}}$ \\
\hline 10 & & 9518 & Inv1 & 1 & $\mathrm{~T}$ & 3 & AT & 1 & $\mathrm{~T}$ & 3 & AT \\
\hline 11 & & 9529 & Oseg & 1 & $\mathrm{~T}$ & 3 & AT & 1 & $\mathrm{~T}$ & 3 & AT \\
\hline 12 & 8 & 9536 & Wulung 1 & 1 & $\bar{T}$ & 3 & $\overline{\mathrm{AT}}$ & 1 & $\mathrm{~T}$ & 5 & $\bar{R}$ \\
\hline 13 & & 9549 & Angkok & 1 & $\mathrm{~T}$ & 3 & $\mathrm{AT}$ & 1 & $\mathrm{~T}$ & 5 & R \\
\hline 14 & 9 & 9522 & Jembar Batan & 1 & $\bar{T}$ & 3 & $\overline{\mathrm{AT}}$ & 3 & $\overline{\mathrm{AT}}$ & 1 & $T$ \\
\hline 15 & & 7259 & Siam 11 & 1 & $\mathrm{~T}$ & 3 & AT & 3 & AT & 3 & AT \\
\hline 16 & & 7860 & Obor Laut & 1 & $\mathrm{~T}$ & 3 & $\mathrm{AT}$ & 3 & $\mathrm{AT}$ & 3 & $\mathrm{AT}$ \\
\hline 17 & & 9523 & Cungkring & 1 & $\mathrm{~T}$ & 3 & $\mathrm{AT}$ & 3 & $\mathrm{AT}$ & 3 & $\mathrm{AT}$ \\
\hline 18 & 10 & 7246 & Kwatek Padang Luas & 1 & $\mathrm{~T}$ & 3 & AT & 3 & $\mathrm{AT}$ & 5 & $\mathrm{R}$ \\
\hline 19 & & 7258 & Saba & 1 & $\mathrm{~T}$ & 3 & AT & 3 & AT & 5 & $\mathrm{R}$ \\
\hline 20 & & 7776 & Tamleg & 1 & $\mathrm{~T}$ & 3 & $\mathrm{AT}$ & 3 & AT & 5 & $\mathrm{R}$ \\
\hline 21 & & 7819 & Ketan Hitam & 1 & $\mathrm{~T}$ & 3 & AT & 3 & AT & 5 & $\mathrm{R}$ \\
\hline 22 & & 9537 & Hawara Kapas 1 & 1 & $\mathrm{~T}$ & 3 & AT & 3 & AT & 5 & $\mathrm{R}$ \\
\hline 23 & & 9548 & Si Denok & 1 & $\mathrm{~T}$ & 3 & $\mathrm{AT}$ & 3 & $\mathrm{AT}$ & 5 & $\mathrm{R}$ \\
\hline 24 & 11 & 9520 & Morneng/Dasneng & 1 & $\mathrm{~T}$ & 3 & AT & 5 & $\mathrm{R}$ & 1 & $T$ \\
\hline
\end{tabular}


tabel lanjutan

\begin{tabular}{|c|c|c|c|c|c|c|c|c|c|c|c|}
\hline 25 & 12 & 7277 & Unus Birayang & 1 & $\mathrm{~T}$ & 3 & $\mathrm{AT}$ & 5 & $\mathrm{R}$ & 3 & AT \\
\hline 26 & & 7306 & Terong Ulang & 1 & $\mathrm{~T}$ & 3 & $\mathrm{AT}$ & 5 & $\mathrm{R}$ & 3 & $\mathrm{AT}$ \\
\hline 27 & & 7837 & Genjah Welut & 1 & $\mathrm{~T}$ & 3 & $\mathrm{AT}$ & 5 & $\mathrm{R}$ & 3 & $\mathrm{AT}$ \\
\hline 28 & & 9586 & Mekar sari & 1 & $\mathrm{~T}$ & 3 & $\mathrm{AT}$ & 5 & $\mathrm{R}$ & 3 & $\mathrm{AT}$ \\
\hline 29 & 13 & 7800 & Pisitan Gundul & 1 & $\mathrm{~T}$ & 3 & $\mathrm{AT}$ & 5 & $\mathrm{R}$ & 5 & $\mathrm{R}$ \\
\hline 30 & & 7857 & Beras Hitam & 1 & $\mathrm{~T}$ & 3 & $\mathrm{AT}$ & 5 & $\mathrm{R}$ & 5 & $\mathrm{R}$ \\
\hline 31 & & 7862 & Ranting Merah & 1 & $\mathrm{~T}$ & 3 & $\mathrm{AT}$ & 5 & $\mathrm{R}$ & 5 & $\mathrm{R}$ \\
\hline 32 & & 9544 & Ketan Putih1 & 1 & $\mathrm{~T}$ & 3 & $\mathrm{AT}$ & 5 & $\mathrm{R}$ & 5 & $\mathrm{R}$ \\
\hline 33 & & 9554 & Muncul- Jati Barang & 1 & $\mathrm{~T}$ & 3 & $\mathrm{AT}$ & 5 & $\mathrm{R}$ & 5 & $\mathrm{R}$ \\
\hline 34 & 14 & 9521 & Jembar Lokal & 1 & $\mathrm{~T}$ & 5 & $\mathrm{R}$ & 3 & $\mathrm{AT}$ & 1 & $\mathrm{~T}$ \\
\hline 35 & 15 & 7276 & Unus & 1 & $\mathrm{~T}$ & 5 & $\mathrm{R}$ & 3 & $\mathrm{AT}$ & 3 & $\mathrm{AT}$ \\
\hline 36 & 16 & 7271 & Siam Rendah & 1 & $\mathrm{~T}$ & 5 & $\mathrm{R}$ & 3 & $\mathrm{AT}$ & 5 & $\mathrm{R}$ \\
\hline 37 & 17 & 9556 & Sabo & 1 & $\mathrm{~T}$ & 5 & $\mathrm{R}$ & 5 & $\mathrm{R}$ & 3 & $\overline{\mathrm{AT}}$ \\
\hline 38 & & 9589 & Padi Mayang sari & 1 & $\mathrm{~T}$ & 7 & $\mathrm{R}$ & 7 & $\mathrm{R}$ & 3 & $\mathrm{AT}$ \\
\hline 39 & & 9591 & Padi Karan Duku & 1 & $\mathrm{~T}$ & 7 & $\mathrm{R}$ & 5 & $\mathrm{R}$ & 3 & $\mathrm{AT}$ \\
\hline 40 & 18 & 9517 & Cere Manggu & 3 & $\mathrm{AT}$ & 1 & $\mathrm{~T}$ & 1 & $\mathrm{~T}$ & 1 & $\mathrm{~T}$ \\
\hline 41 & & 9524 & Nengsih & 3 & $\mathrm{AT}$ & 1 & $\mathrm{~T}$ & 1 & $\mathrm{~T}$ & 1 & $\mathrm{~T}$ \\
\hline 42 & 19 & 7877 & $\begin{array}{l}\text { Semati (Ciherang/Sri } \\
\text { Putih) }\end{array}$ & 3 & AT & 1 & $\mathrm{~T}$ & 1 & $\mathrm{~T}$ & 3 & AT \\
\hline 43 & 20 & 7813 & Pare siriendah & 3 & $\mathrm{AT}$ & 1 & $\mathrm{~T}$ & 3 & $\mathrm{AT}$ & 3 & $\mathrm{AT}$ \\
\hline 44 & & 7873 & Basmati Sukamandi & 3 & $\mathrm{AT}$ & 1 & $\mathrm{~T}$ & 3 & $\mathrm{AT}$ & 3 & $\mathrm{AT}$ \\
\hline 45 & & 7917 & Pae Ndina Ana & 3 & $\mathrm{AT}$ & 1 & $\mathrm{~T}$ & 3 & $\mathrm{AT}$ & 3 & $\mathrm{AT}$ \\
\hline 46 & 21 & 9543 & Cere & 3 & $\mathrm{AT}$ & 1 & $\mathrm{~T}$ & 5 & $\mathrm{R}$ & 3 & $\mathrm{AT}$ \\
\hline 47 & 22 & 7863 & Gombal & 3 & $\mathrm{AT}$ & 3 & $\mathrm{AT}$ & 1 & $\mathrm{~T}$ & 3 & $\mathrm{AT}$ \\
\hline 48 & & 7964 & Djambon & 3 & $\mathrm{AT}$ & 3 & $\mathrm{AT}$ & 1 & $\mathrm{~T}$ & 3 & $\mathrm{AT}$ \\
\hline 49 & & 9514 & Lamdaur Ekor Hitam & 3 & $\mathrm{AT}$ & 3 & $\mathrm{AT}$ & 1 & $\mathrm{~T}$ & 3 & $\mathrm{AT}$ \\
\hline 50 & & 9515 & Kewal Bereum & 3 & AT & 3 & AT & 1 & $\mathrm{~T}$ & 3 & AT \\
\hline 51 & & 9531 & Cere1 & 3 & $\mathrm{AT}$ & 3 & $\mathrm{AT}$ & 1 & $\mathrm{~T}$ & 3 & $\mathrm{AT}$ \\
\hline 52 & 23 & 9540 & Hawara Kapas 2 & 3 & $\mathrm{AT}$ & 3 & $\mathrm{AT}$ & 1 & $\mathrm{~T}$ & 5 & $\mathrm{R}$ \\
\hline 53 & & 9555 & Borang & 3 & $\mathrm{AT}$ & 3 & $\mathrm{AT}$ & 1 & $\mathrm{~T}$ & 5 & $\mathrm{R}$ \\
\hline 54 & 24 & 9528 & Menyan & 3 & $\mathrm{AT}$ & 3 & $\mathrm{AT}$ & 3 & $\mathrm{AT}$ & 1 & $\mathrm{~T}$ \\
\hline 55 & 25 & 7872 & $\begin{array}{l}\text { Darma Ayu iherang } \\
\text { /Sri putih) }\end{array}$ & 3 & AT & 3 & $\mathrm{AT}$ & 3 & $\mathrm{AT}$ & 3 & $\mathrm{AT}$ \\
\hline 56 & & 7961 & Yoing & 3 & $\mathrm{AT}$ & 3 & $\mathrm{AT}$ & 3 & $\mathrm{AT}$ & 3 & AT \\
\hline 57 & & 9571 & Cekow & 3 & $\mathrm{AT}$ & 3 & $\mathrm{AT}$ & 3 & $\mathrm{AT}$ & 3 & $\mathrm{AT}$ \\
\hline 58 & 26 & 9535 & Ketan Pecut 2 & 3 & $\mathrm{AT}$ & 3 & $\mathrm{AT}$ & 3 & $\mathrm{AT}$ & 5 & $\mathrm{R}$ \\
\hline 59 & & 9551 & Kebo & 3 & AT & 3 & AT & 3 & AT & 5 & $\mathrm{R}$ \\
\hline 60 & & 9572 & Padi Bujang Berinai & 3 & $\mathrm{AT}$ & 3 & $\mathrm{AT}$ & 3 & $\mathrm{AT}$ & 5 & $\mathrm{R}$ \\
\hline 61 & 27 & 78381 & Rembang & 3 & $\mathrm{AT}$ & 3 & $\mathrm{AT}$ & 5 & $\mathrm{R}$ & 3 & $\mathrm{AT}$ \\
\hline 62 & 28 & 7932 & Gundil & 3 & $\mathrm{AT}$ & 3 & $\mathrm{AT}$ & 5 & $\mathrm{R}$ & 5 & $\mathrm{R}$ \\
\hline 63 & & 79871 & Padi Burungan & 3 & $\mathrm{AT}$ & 3 & AT & 5 & $\mathrm{R}$ & 5 & $\mathrm{R}$ \\
\hline 64 & & 9533 & Cere 3 & 3 & AT & 3 & $\mathrm{AT}$ & 5 & $\mathrm{R}$ & 5 & $\mathrm{R}$ \\
\hline 65 & & 9573 & Cekow & 3 & $\mathrm{AT}$ & 3 & $\mathrm{AT}$ & 5 & $\mathrm{R}$ & 5 & $\mathrm{R}$ \\
\hline
\end{tabular}




\begin{tabular}{|c|c|c|c|c|c|c|c|c|c|c|c|}
\hline 66 & 29 & 9541 & Lokcan Empok & 3 & $\mathrm{AT}$ & 5 & $\mathrm{R}$ & 1 & $\mathrm{~T}$ & 3 & AT \\
\hline 67 & 30 & 7991 & Srijaya Panjang & 3 & $\mathrm{AT}$ & 5 & $\mathrm{R}$ & 3 & $\mathrm{AT}$ & 1 & $\mathrm{~T}$ \\
\hline 68 & 31 & 7274 & $\begin{array}{l}\text { Siam unus } \\
\text { Kuning Tanbak } \\
\text { Sariah }\end{array}$ & 3 & $\mathrm{AT}$ & 5 & $\mathrm{R}$ & 3 & $\mathrm{AT}$ & 3 & AT \\
\hline 69 & & 7292 & Monsua & 3 & $\mathrm{AT}$ & 5 & $\mathrm{R}$ & 3 & $\mathrm{AT}$ & 3 & $\mathrm{AT}$ \\
\hline 70 & & 7856 & Beras Hitam & 3 & $\mathrm{AT}$ & 5 & $\mathrm{R}$ & 3 & $\mathrm{AT}$ & 3 & $\mathrm{AT}$ \\
\hline 71 & & 7868 & Si Udang & 3 & $\mathrm{AT}$ & 5 & $\mathrm{R}$ & 3 & $\mathrm{AT}$ & 3 & $\mathrm{AT}$ \\
\hline 72 & & 7933 & Kantuna & 3 & AT & 5 & $\mathrm{R}$ & 3 & $\mathrm{AT}$ & 3 & $\mathrm{AT}$ \\
\hline 73 & & 9545 & Ketan Putih & 3 & $\mathrm{AT}$ & 5 & $\mathrm{R}$ & 3 & $\mathrm{AT}$ & 3 & $\mathrm{AT}$ \\
\hline 74 & 32 & 7960 & Itum & 3 & $\mathrm{AT}$ & 5 & $\mathrm{R}$ & 3 & $\mathrm{AT}$ & 5 & $\mathrm{R}$ \\
\hline 75 & & 9542 & Wulung 2 & 3 & $\mathrm{AT}$ & 5 & $\mathrm{R}$ & 3 & $\mathrm{AT}$ & 5 & $\mathrm{R}$ \\
\hline 76 & 33 & 9570 & Padi Pulut Hitam & 3 & $\mathrm{AT}$ & 5 & $\mathrm{R}$ & 7 & $\mathrm{R}$ & 3 & $\mathrm{AT}$ \\
\hline 77 & & 9585 & Padi Karia & 3 & $\mathrm{AT}$ & 5 & $\mathrm{R}$ & 7 & $\mathrm{R}$ & 3 & $\mathrm{AT}$ \\
\hline 78 & 34 & 9553 & Kebo Super & 3 & $\mathrm{AT}$ & 5 & $\mathrm{R}$ & 5 & $\mathrm{R}$ & 5 & $\mathrm{R}$ \\
\hline 79 & & 9563 & $\begin{array}{l}\text { Padi Sigading } \\
\text { Merah }\end{array}$ & 3 & $\mathrm{AT}$ & 5 & $\mathrm{R}$ & 5 & R & 5 & $\mathrm{R}$ \\
\hline 80 & 35 & 7848 & $\begin{array}{l}\text { Ciherang (tahan } \\
\text { BLB) }\end{array}$ & 5 & $\mathrm{R}$ & 1 & $\mathrm{~T}$ & 3 & $\mathrm{AT}$ & 1 & $\mathrm{~T}$ \\
\hline 81 & 36 & 8163 & Soponyono & 5 & $\mathrm{R}$ & 1 & T & 3 & AT & 3 & $\mathrm{AT}$ \\
\hline 82 & 37 & 7782 & Padi Terong & 5 & $\mathrm{R}$ & 3 & $\mathrm{AT}$ & 1 & $\mathrm{~T}$ & 5 & $\mathrm{R}$ \\
\hline 83 & 38 & 7821 & Pare Salak & 5 & $\mathrm{R}$ & 3 & $\mathrm{AT}$ & 3 & $\mathrm{AT}$ & 1 & $\mathrm{~T}$ \\
\hline 84 & 39 & 7834 & Cere Dota & 5 & $\mathrm{R}$ & 3 & $\mathrm{AT}$ & 3 & $\mathrm{AT}$ & 3 & $\mathrm{AT}$ \\
\hline 85 & & 7916 & Pae Lolo & 5 & $\mathrm{R}$ & 3 & $\mathrm{AT}$ & 3 & AT & 3 & $\mathrm{AT}$ \\
\hline 86 & & 7963 & HS3 & 5 & $\mathrm{R}$ & 3 & $\mathrm{AT}$ & 3 & AT & 3 & AT \\
\hline 87 & & 9565 & Padi Bau & 5 & $\mathrm{R}$ & 3 & $\mathrm{AT}$ & 3 & AT & 3 & $\mathrm{AT}$ \\
\hline 88 & & 9575 & $\begin{array}{ll}\text { Padi } & \text { Pulut } \\
\text { Belanda } & \end{array}$ & 5 & $\mathrm{R}$ & 3 & AT & 3 & AT & 3 & $\mathrm{AT}$ \\
\hline 89 & 40 & 9579 & Padi Anak Ulat & 5 & $\mathrm{R}$ & 3 & $\mathrm{AT}$ & 3 & $\mathrm{AT}$ & 5 & $\mathrm{R}$ \\
\hline 90 & & 9587 & Padi KKB & 7 & $\mathrm{R}$ & 3 & $\mathrm{AT}$ & 3 & $\mathrm{AT}$ & 7 & $\mathrm{R}$ \\
\hline 91 & 41 & 9580 & Burung & 7 & $\mathrm{R}$ & 3 & $\mathrm{AT}$ & 5 & $\mathrm{R}$ & 7 & $\mathrm{R}$ \\
\hline 92 & 42 & 7869 & Srijaya (bulat) & 5 & $\mathrm{R}$ & 5 & $\mathrm{R}$ & 3 & $\mathrm{AT}$ & 3 & $\mathrm{AT}$ \\
\hline 93 & 43 & 7968 & Djedah & 5 & $\mathrm{R}$ & 5 & $\mathrm{R}$ & 5 & $\mathrm{R}$ & 1 & $\mathrm{~T}$ \\
\hline 94 & 44 & 7855 & Beras Hitam (2) & 5 & $\mathrm{R}$ & 5 & $\mathrm{R}$ & 5 & $\mathrm{R}$ & 3 & $\mathrm{AT}$ \\
\hline 95 & 45 & 9584 & Kuro & 5 & $\mathrm{R}$ & 7 & $\mathrm{R}$ & 5 & $\mathrm{R}$ & 5 & $\mathrm{R}$ \\
\hline 96 & & 9583 & Padi Napal & 5 & $\mathrm{R}$ & 5 & $\mathrm{R}$ & 7 & $\mathrm{R}$ & 7 & $\mathrm{R}$ \\
\hline 97 & & 9582 & Kuriak & 5 & $\mathrm{R}$ & 7 & $\mathrm{R}$ & 5 & $\mathrm{R}$ & 7 & $\mathrm{R}$ \\
\hline 98 & & 9568 & $\begin{array}{l}\text { Padi Ketik } \\
\text { Nibung }\end{array}$ & 7 & $\mathrm{R}$ & 5 & $\mathrm{R}$ & 7 & $\mathrm{R}$ & 7 & $\mathrm{R}$ \\
\hline
\end{tabular}




\begin{tabular}{|c|c|c|c|c|c|c|c|c|c|c|}
\hline 99 & 9567 & $\begin{array}{l}\text { Padi Gading } \\
\text { Tinggi }\end{array}$ & 7 & $\mathrm{R}$ & 7 & $\mathrm{R}$ & 7 & $\mathrm{R}$ & 7 & $\mathrm{R}$ \\
\hline 100 & 9566 & $\begin{array}{l}\text { Padi Sigading } \\
\text { Putih }\end{array}$ & 7 & $\mathrm{R}$ & 7 & $\mathrm{R}$ & 7 & $\mathrm{R}$ & 7 & $\mathrm{R}$ \\
\hline 101 & 7858 & Beras Hitam (1) & 5 & $\mathrm{R}$ & 5 & $\mathrm{R}$ & 5 & $\mathrm{R}$ & 5 & $\mathrm{R}$ \\
\hline 102 & & $\begin{array}{l}\text { Kencana Bali } \\
\text { (kontrol rentan) }\end{array}$ & 7 & R & 7 & R & 7 & $\mathrm{R}$ & 9 & $\mathrm{R}$ \\
\hline
\end{tabular}

Keterangan $: \mathrm{T}=$ Tahan; $\mathrm{AT}=$ Agak Tahan; $\mathrm{R}=$ Rentan

Varietas-varietas padi lokal yang menunjukkan respon tahan atau agak tahan terhadap 3 atau 4 ras 033, 073, 133 dan 173 dapat dimanfaatkan untuk program pemuliaan tanaman dalam upaya mendapatkan varietas padi yang tahan blas. Varietas-varietas padi lokal tersebut diduga memiliki lebih dari 1 gen ketahanan terhadap penyakit blas. Pada kondisi lapang, umumnya varietas padi lokal menunjukkan kestabilan yang tinggi terhadap penyakit blas, hal ini diduga disebabkan karena adanya keragaman yang tinggi pada varietas padi lokal. Dengan demikian varietas padi lokal tersebut diduga mempunyai ketahanan horisontal. Ketahanan horisontal merupakan ekspresi dari banyak gen (poligenik) dan mampu mengatasi beberapa ras cendawan. Ketahanan horisontal ini bersifat tidak spesifik terhadap ras tertentu. Ketahanan horisontal tidak sepenuhnya memberikan pertahanan tanaman yang tinggi terhadap suatu ras tetapi mencegah perkembangan lanjut dari berbagai ras suatu patogen. Ketahanan horisontal memberikan ketahanan yang lebih stabil untuk pengendalian penyakit blas dengan penggunaan varietas tahan (Wang et al., 2010).

Cendawan patogen penyebab penyakit blas mudah membentuk ras baru dengan tingkat virulensi tinggi sehingga dengan cepat dapat mematahkan ketahanan varietas (Yulianto, 2017). Penyakit blas memiliki sebaran dan jumlah ras berbeda-beda pada setiap lokasi (Sudir et al., 2014). Oleh karena itu, varietas padi yang mempunyai lebih dari 1 gen ketahanan menjadi penting untuk menghadapi berbagai macam ras penyakit blas. Selain itu, varietas padi lokal yang mempunyai ketahanan (tahan atau agak tahan) terhadap 3 atau 4 ras sebaiknya perlu dilakukan identifikasi gen -gen yang terdapat pada varietas padi lokal tersebut. Diharapkan dari varietas padi lokal tersebut diperoleh gen-gen novel terhadap patogen blas yang berbeda dari gen-gen ketahanan penyakit blas yang sudah teridentifikasi sebelumnya. Salah satu gen ketahanan terhadap penyakit blas adalah gen Pirf2-1(t) dan Pir2-3(t) yang diisolasi dari kromosom 2 varietas liar $O$. rufipogon dan varietas budidaya IR 64 (Utami et al., 2005).
Tabel 4. Asal daerah varietas padi lokal yang mempunyai respon tahan atau agak tahan terhadap ras 033, 073, 133 dan 173

\begin{tabular}{|c|c|c|c|c|c|}
\hline \multirow{2}{*}{ No. } & \multirow{2}{*}{$\begin{array}{c}\text { Pola } \\
\text { respon } \\
\text { ketahanan }\end{array}$} & \multirow{2}{*}{ No. Aksesi } & \multirow{2}{*}{ Nama Varietas } & \multicolumn{2}{|c|}{ Asal Daerah } \\
\hline & & & & Provinsi & Kabupaten \\
\hline 1 & 1 & 9525 & Cere Bereum & Jawa Barat & Bandung \\
\hline 2 & 2 & 9526 & Jember & Jawa Barat & Tasikmalaya \\
\hline 3 & & 9527 & Cere 2 & Jawa Barat & Garut \\
\hline 4 & 3 & 9519 & $\begin{array}{l}\text { Enud-Rawa } \\
\text { Bogo }\end{array}$ & Jawa Barat & Cianjur \\
\hline 5 & 6 & 9547 & Muncul & Jawa Barat & Subang \\
\hline 6 & 7 & 7878 & Merdeka & - & - \\
\hline 7 & & 9518 & Inul & Jawa Barat & Cianjur \\
\hline 8 & & 9529 & Oseg & Jawa Barat & Garut \\
\hline 9 & 9 & 9522 & Jembar Batan & Jawa Barat & Bandung \\
\hline 10 & & 7259 & Siam 11 & - & - \\
\hline 11 & & 7860 & Obor Laut & Jawa Barat & Bandung \\
\hline 12 & & 9523 & Cungkring & Jawa Barat & Bandung \\
\hline 13 & 18 & 9517 & Cere Manggu & Jawa Barat & Cianjur \\
\hline 14 & & 9524 & Nengsih & Jawa Barat & Bandung \\
\hline 15 & 19 & 7877 & $\begin{array}{l}\text { Semati } \\
\text { (Ciherang/Sri } \\
\text { Putih) }\end{array}$ & - & - \\
\hline 16 & 20 & 7813 & Pare Siriendah & Banten & Pandeglang \\
\hline 17 & & 7873 & $\begin{array}{l}\text { Basmati } \\
\text { Sukamandi }\end{array}$ & - & - \\
\hline 18 & & 7917 & Pae Ndina Ana & awesi Tengg & Conawe Selatan \\
\hline 19 & 22 & 7863 & Gombal & - & - \\
\hline 20 & & 7964 & Djambon & - & - \\
\hline 21 & & 9514 & $\begin{array}{l}\text { Lamdaur Ekor } \\
\text { Hitam }\end{array}$ & Jawa Barat & Cianjur \\
\hline 22 & & 9515 & Kewal Bereum & Jawa Barat & Cianjur \\
\hline 23 & & 9531 & Cere1 & Jawa Barat & Garut \\
\hline 24 & 24 & 9528 & Menyan & Jawa Barat & Garut \\
\hline 25 & 25 & 7872 & $\begin{array}{l}\text { Darma Ayu } \\
\text { iherang /Sri } \\
\text { putih) }\end{array}$ & - & - \\
\hline 26 & & 7961 & Yoing & - & - \\
\hline 27 & & 9571 & Cekow & Riau & Pelelawan \\
\hline
\end{tabular}


Pola respon ketahanan lainnya bervariasi yaitu tahan atau agak tahan terhadap 1 atau 2 ras. Varietas padi lokal Djedah dan Beras Hitam (2) merupakan varietas padi lokal yang mempunyai respon spesifik terhadap 1 ras yaitu ras 173 (Tabel 3). Varietas padi lokal Djedah menunjukkan respon tahan, sedangkan Beras Hitam (2) mempunyai respon agak tahan terhadap ras 173 (pola respon ketahanan 43 dan 44). Ketahanan yang terdapat pada varietas padi lokal Djedah dan Beras Hitam (2) diduga merupakan ketahanan vertikal. Ketahanan vertikal pada umumnya sifat ketahanannya tidak stabil atau mudah patah ketahanannya setelah beberapa musim tanam. Ketahanan vertikal adalah ketahanan yang ditentukan oleh satu atau sedikit gen atau ketahanan terhadap ras patogen tertentu, tetapi tidak pada ras lainnya (Semangun 2008).

Berbeda dengan pola respon ketahanan 1, respon yang berlawanan terdapat pada pola respon ketahanan 45 yang merupakan kelompok varietas-varietas padi lokal yang rentan terhadap semua ras yang digunakan, termasuk adalah varietas Kencana Bali yang merupakan varietas kontrol atau pembanding rentan terhadap penyakit blas. Varietas-varietas padi lokal yang menunjukkan respon rentan terhadap semua patogen yang digunakan adalah Kuro, Padi Napal, Kuriak, Padi Ketik Nibung, Padi Gading Tinggi, Padi Sigading Putih dan Beras Hitam (1). Varietas padi lokal tersebut dan Kencana Bali diduga tidak memiliki gen ketahanan terhadap patogen $P$. grisea sehingga ekspresinya rentan terhadap semua ras yang digunakan.

Reaksi patogen $P$. grisea ras 033, 073, 133, dan 173 terhadap 100 varietas padi lokal yang diuji terlihat pada Tabel 5. Berdasarkan hasil penelitian diketahui bahwa ras 033, 073, 133 dan 173 mempunyai reaksi virulen terhadap masing-masing 22,30 , 35 dan 39 varietas padi lokal, dan avirulen terhadap 78, 70, 65 dan 61 varietas. Reaksi virulen merupakan reaksi kompatibel antara patogen dan tanaman inang dalam hal ini varietas padi lokal sehingga menyebabkan tanaman inang rentan terhadap patogen tersebut, sedangkan avirulen adalah reaksi inkompatibel antara patogen dan tanaman inang sehingga menyebabkan tanaman mempunyai respon tahan terhadap patogen. Agrios (2005) menyatakan bahwa terdapat dua bentuk interaksi, yaitu reaksi inkompatibel dan kompatibel. Interaksi inkompatibel adalah interaksi antara gen resisten ( $\mathrm{R}$ gene) pada tanaman inang dengan gen avirulen (Avr) pada patogen yang selanjutnya menyebabkan terbentuknya reaksi hipersensitif (HR) pada tanaman inang, sedangkan interaksi kompatibel adalah interaksi antara tanaman inang yang rentan dengan patogen yang virulen hingga menyebabkan timbulnya penyakit.

Berdasarkan hasil tersebut, diduga bahwa ras 133 dan 173 mempunyai tingkat virulensi yang lebih tinggi dibandingkan ras 033 dan 073 terhadap varietas padi lokal. Ras 133 yang berasal dari Sukabumi merupakan ras dengan tingkat virulensi tinggi, sedangkan ras 033 (Sukabumi) dan ras 073 (Indramayu) memiliki tingkat virulensi sedang (Nasution et al., 2007). Indrayani et al. (2013) menduga patogen blas ras 073 dan 133 memiliki tingkat virulensi yang lebih tinggi dibandingkan ras 033. Menurut Mogi et al. (1991), bahwa berdasarkan reaksi terhadap varietas differensial Indonesia diketahui ras 173 mempunyai tingkat virulensi lebih tinggi dibandingkan ras 033, 073 dan 133.

Tabel 5. Reaksi patogen $P$. grisea ras 033, 073, 133, dan 173 terhadap varietas padi lokal

\begin{tabular}{|c|c|c|c|c|}
\hline \multirow{2}{*}{ Reaksi } & \multicolumn{4}{|c|}{ Ras $P$. grisea } \\
\hline & 33 & 73 & 133 & 173 \\
\hline Avirulen & 78 & 70 & 65 & 61 \\
\hline Virulen & 22 & 30 & 35 & 39 \\
\hline Jumlah & 100 & 100 & 100 & 100 \\
\hline
\end{tabular}

Patogen penyebab penyakit blas memiliki banyak sekali ras. Menurut Santoso \& Nasution (2012), di Indonesia terdapat lebih dari 30 ras yang teridentifikasi menggunakan varietas diferensial Indonesia. Hasil penelitian Santoso et al. (2019), bahwa ras Pyricularia asal Papua yang diidentifikasi terdiri atas sembilan kelompok yaitu ras 211, 213, 241, 251, 253, $313,333,353$ dan 373. Ras yang dominan adalah ras 333 dengan komposisi $41,18 \%$ dan ras 373 dengan komposisi $33.35 \%$. Ras Pyricularia yang diperoleh mempunyai tingkat virulensi yang tinggi. Variasi genetik dan fenotipik populasi patogen blas dari beberapa daerah endemik dapat memberikan sumbangan yang besar dalam pemilihan isolat yang sesuai untuk karakterisasi genetik dan berguna dalam perakitan varietas tahan blas yang durable atau stabil (Santoso et al., 2007).

\section{KESIMPULAN}

Varietas padi lokal mempunyai keragaman genetik yang tinggi terhadap penyakit blas daun. Didapatkan 45 pola respon ketahanan varietas padi lokal yang diuji terhadap ras 033, 073, 133 dan 173.

Varietas padi lokal yang menunjukkan respon tahan atau agak tahan terhadap ras 033, 073, 133 dan 173 adalah Cere Bereum, Jember, Cere 2, Enud-Rawa Bogo, Muncul, Inul, Oseg, Jembar Batan, Siam 11, Obor Laut, Cungkring, Cere Manggu, Nengsih, Semati, Pare Siriendah, Basmati Sukamandi, Pae Ndina Ana, Gombal, Djambon, Lamdaur Ekor Hitam, Kewal Bereum, Cere 1, Menyan, Darma Ayu, Yoing dan Cekow.

Varietas padi lokal Djedah dan Beras Hitam (2) merupakan varietas padi lokal yang mempunyai respon spesifik terhadap ras 173 .

Ras 133 dan 173 mempunyai tingkat virulensi 
yang lebih tinggi dibandingkan ras 033 dan 073 terhadap varietas padi lokal.

\section{DAFTAR PUSTAKA}

Agrios, G. N. (2005). Plant Pathology. Fifth Edition. Elsevier Academic Press., USA.

Balai Besar Peramalan Organisme Pengganggu Tanaman. (2019). Laporan Kinerja BBPOPT Tahun 2018. Balai Besar Peramalan Organisme Pengganggu Tanaman. Direktorat Jenderal Tanaman Pangan. Kementerian Pertanian, Jakarta.

Hairmansis A., Supartopo, Yullianida, Sunaryo, Warsono, Sukirman \& Suwarno. (2015). Pemanfaatan plasma nutfah padi (Oryza sativa) untuk perbaikan sifat padi gogo. Pros Semnas Masy Biodiv Indon. 1(1), 14-18. DOI : https://10.13057/psnmbi/ m010102.

Indrayani, S., Nasution, A. \& Mulyaningsih, E. S. (2013). Analisis ketahanan padi gogo dan padi sawah (Oryza sativa L) terhadap empat ras penyakit blas (Pyricularia grisea Sacc). Jurnal Agricola, 3(1), 53-62. DOI: https:// doi.org/10.35724/ag.v3i1.118.

IRRI [International Rice Research Institute]. (2014). Standart evaluation system for rice. $5^{\text {ed }}$. IRRI, Los Banos, Philippines.

Kharisma, S., Desi A., Cholil \& Aini, L. Q. (2013). Ketahanan beberapa genotipe padi hibrida (Oryza sativa L.). Jurnal HPT, 1(2), 19-27.

Mogi, S., Sugandhi, Z., Baskoro, S. W., Edwina, R. \& Cahyadi, I. (1991). Establishment of the Differential Variety Series for Pathogenic Race Identification of Rice Blast fungus and the Distribution of Race Based on the New Differential Indonesia. Rice Disease Study Guup Karawang. Jatisari, Indonesia.

Nasution, A., Santoso \& Puspitarati, T. (2007). Respon varietas padi lokal terhadap lima ras Pyricularia grisea. Apresiasi Hasil Penelitian Padi.

Nasution, A., Santoso \& Sudir. (2013). Pemetaan ras blas (Pyricularia grisea) yang menyerang padi sawah di daerah Jawa Barat. Buku 2. hlm. 1093-1104. In Abdulrachman, S., Pratiwi, G.R., Ruskandar, A., Nuryanto, B., Usyati, N., Widyantoro, Guswara, A., Samita, P., Mejaya, M. J., (Ed.). Prosiding Seminar Nasional Inovasi Teknologi Adaptip Perubahan Iklim Global Mendukung Surplus 10 Juta ton Beras Tahun 2014. Badan Penelitian dan Pengembangan Pertanian, Kementerian Pertanian, Jakarta.

Nasution, A. \& Usyati, N. (2015). Observasi ketahanan varietas padi lokal terhadap penyakit blas (Pyricularia grisea) di rumah kaca. Pros Semnas Masy Biodiv Indon. 1(1). DOI: https://doi.org/ 10.13057/ psnmbi/m010103.

Ou, S.H. (1985). Rice Blast Disease. 2nd ed. Commonwealth Mycological Institute Kew, Surrey, England.
Prabawa, P.S., Yulianah, I., \& Basuki, N. (2015). Uji ketahanan 10 genotip padi merah (Oryza sativa L.) terhadap penyakit blas daun ras 173. Jurnal Produksi Tanaman, 3(6), 496 - 502. DOI : https://10.21176/protan.v3i6.227.

Rossman, A. Y., Howard, R. .J. \& Valent. (1990). Pyricularia grisea, the correct name for the blast fungus. Mycology, 82, 509-512. DOI : https:// 10.2307/3760024.

Santoso \& Nasution, N. (2008). Pengendalian penyakit blas dan penyakit cendawan lainnya. Buku Padi 2. hlm. 531-563. In Darajat, A. A., Setyono, A. dan Makarim, A.K. dan Hasanuddin, A. (Ed.). Padi Inovasi Teknologi. Balai Besar Penelitian Tanaman Padi, Badan Penelitian dan Pengembangan Pertanian, Sukamandi.

Santoso, Nasution, N., Utami, D. W., Hanarida, I., Ambarwati, A. D., Moeljopawiro, S. \& Tharreau, D. (2007). Variasi Genetik dan Spektrum Virulensi Patogen Blas pada Padi Asal Jawa Barat dan Sumatera. Penelitian Pertanian Tanaman Pangan, 26(3), 150 - 155.

Santoso, Sipi, S., Subiadi, \& Nasution, A. (2019). Keragaman Ras Pyricularia grisea Penyebab Penyakit Blas pada Tanaman Padi Sawah Papua Barat Penelitian Pertanian Tanaman Pangan. 3(1), 1-8.DOI: http//dx.doi.org/10.21082/ jpptp.v3n1.2019.p1-8.

Semangun, H. (2008). Penyakit-penyakit Tanaman Pangan di Indonesia (Edisi Kedua). Gadjah Mada University Press., Yogyakarta.

Sharma, T. R., Rai, A. K., Gupta, S. K., Vijayan, J., Devanna, B. N. \& Ray, S. (2012). Rice blast management through host-plant resistance: retrospect and prospects. Agric. Res., 1, 37-52. DOI: https://10.1007/s40003-011-0003-5.

Sitaresmi, T., Rina, H. W., Ami, T. R., Yunani, N. \& Susanto, U. (2013). Pemanfaatan padi varietas lokal dalam perakitan varietas unggul. Iptek Tanaman Pangan, 8(1), 22-30.

Subiadi, Sipi, S. \& Motulo, H. F.J. (2016). Estimasi kehilangan hasil padi akibat serangan penyakit blas leher. hlm. 377-385. In H. Syahbuddin, J.G. Kindangen, L.A. Taulu, P.C. Paat, G.H. Josep dan R. Hendayana (eds). Prosiding Seminar Nasional Akselerasi Agroinovasi Berbasis Sumberdaya Lokal Menuju Kemandirian Pangan. Manado. Balai Besar Pengembangan dan Pengkajian Teknologi Pertanian.

Sudir, Nasution, N., Santoso, \& Nuryanto, B. (2014). Penyakit blas Pyricularia grisea pada tanaman padi dan strategi pengendaliannya. Iptek Tanaman Pangan, 9(2), 85-96.

Suganda, T., Yulia, E., Widantini, F. \& Hersanti. (2016). Intensitas penyakit blas (Pyricularia oryzae Cav.) pada padi varietas Ciherang dan pengaruhnya terhadap kehilangan hasil. Jurnal Agrikultura, 
27(3),154-159. DOI: https://doi.org/10.24198/ agrikultura.v27i3.10878.

Turaidar, V., Reddy, M., R., Anantapur, Krupa, K. N., Dalawai, N., Deepak, C. A. \& Harini Kumar, K. M. (2018). Screening of traditional rice varieties (TRVs) for blast resistance. Journal of Pharmacognosy and Phytochemistry. 7(1), 1384-1388

Utami, D. W., Aswidinnoor, H., Moeljopawiro, S., Hanarida, I. \& Refinur. (2006). Pewarisan Ketahanan Penyakit Blas (Pyricularia grisea Sacc.) pada Persilangan Padi IR64 dengan Oryza rufipogon
Griff. Hayati, 13(3), 107-112. DOI: https:// doi.org/10.1016/S1978-3019(16)30302-3.

Wang, X., Fjellstrom, R., Jia, Y., Yan, W. G., Jia, M.H.\&Scheffler,B.E.(2010).

Characterization of Pita blast resistance gene in an international rice core collection. Plant Breed.129, 491-501. DOI: https://10.1111/j.14390523.2009. 01706.x

Yulianto. (2017). Ketahanan varietas padi lokal Mentik wangi terhadap penyakit blas. Journal of Food System and Agribusiness,1(1),47-54. DOI: https://doi.org/10.25181/jofsa.v1i1. 83 